\title{
Finite Element Analysis of a Cofferdam with Bucket Foundations at Zhuanghai Artificial Island
}

\author{
Jianhong Zhang* and Xingxing Zhang
}

State Key Laboratory of Hydroscience and Engineering, Tsinghua University Beijing, 100084, China

\begin{abstract}
This paper presents a finite element study of the stability and deformation of a cofferdam incorporating bucket foundations in soft clays at Zhuanghai Artificial Island. The development of excess pore pressures in the clays has been investigated in terms of the progress of construction, geometry of structures and hence the load resulted. The effect of prefabricated drains on the behavior of the soil-structure system has been highlighted.
\end{abstract}

Keywords: Finite element method, bucket foundation, prefabricated drains.

\section{INTRODUCTION}

About $3.0 \times 10^{8} \mathrm{t}$ petroleum geological reserves have been recently detected in Bohai Bay, thus several oil fields are planned to be built. However, the safety of offshore structures is threatened by severe marine environment, such as energetic wave regime, strong influence of tides and currents and poor soil conditions. The stability of soil-structure systems on soft clays is one of the most concerned problems.

Suction bucket foundations have been applied increasingly often in offshore engineering [1]. The convenience of installation and repeat use is one of the most outstanding advantages. Physical and numerical simulations are the two main methods in safety evaluations of the structures. Great efforts have been taken in both areas on bearing capacity, deformation, dynamic behaviors, etc, of bucket foundations. For example, Dyvik et al. [2,3] performed a series of $1 \mathrm{~g}$ model tests on bucket foundations. Allard et al. [4] later reported their centrifuge model tests of bucket foundations on very dense sand for gravity platform. El-Ghbarbawy and Olson [5] investigated the cyclic pullout capacity of suction caisson foundations. Zhang et al. [6] conducted a series centrifuge model tests to study the dynamic behaviors of suction buckets under cyclic lateral loadings. Finite element analysis has been used quite often in numerical evaluation of marine structures in soft clay. Wu et al. [7] performed finite element analyses to evaluate the ultimate bearing capacity of bucket foundations in undrained soft clay under vertical force, horizontal force and moment. Effects of aspect ratio of bucket foundation and shear strength of soft soil were studied. Zhang et al. [8,9] performed finite element analysis to study the stability of jetties and breakwaters at Huanghua Port.

Zhuanghai artificial island is located at a shallow water area of Bohai Sea, $6 \mathrm{~km}$ to the east of Huanghua city. It has two main functions: first, accommodating oil well fields with annual production of about $1.93 \times 10^{5} \mathrm{t}$, then, being a base for

*Address correspondence to this author at the State Key Laboratory of Hydroscience and Engineering, Tsinghua University Beijing, 100084, China; Tel: 861062792984; E-mail: cezhangjh@mail.tsinghua.edu.cn shipping, maritime emergency response and debarkation. Fig. (1) shows the the cofferdam of Zhuanghai artificial island. The cofferdam consists of a retaining wall of a large diameter reinforced concrete cylinder rested on two suction installed steel buckets. These two steel buckets, with a space of $1.0 \mathrm{~m}$, were connected by welding steel plate. The external diameter of the reinforced concrete cylinder and the steel bucket is identical, i.e. $10.5 \mathrm{~m}$.

Because of the presence of soft clays, excess pore pressures will develop during construction and its value will be associated with the construction rate and procedures. The excess pore water pressure will result in reduction of the shear strength of soil, thus significantly affect the occurrence of shear failure in foundation soils. Prefabricated drains were used to improve the soils as shown in Fig. (1). The cofferdam during construction is likely to be the most critical situation as far as excess pore pressure and its effect on the stability of the structures is concerned.

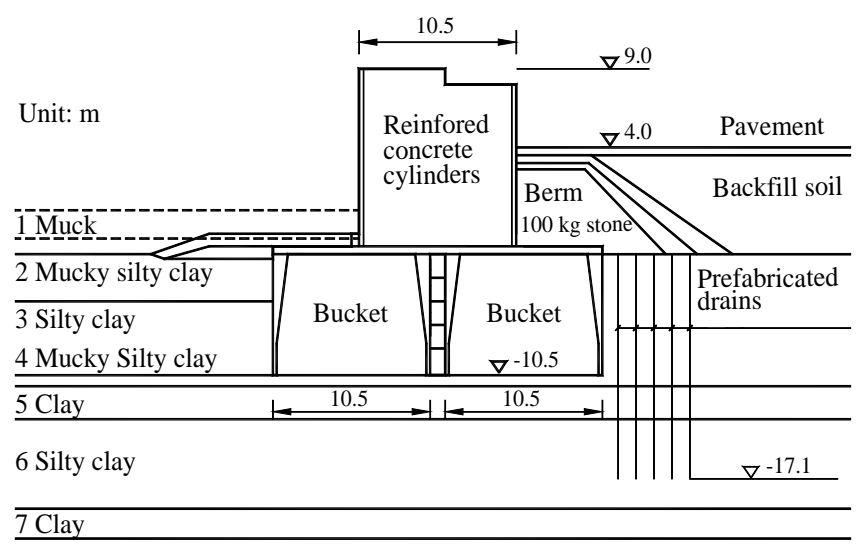

8 Fine sand

9 Silty clay

Fig. (1). Configurations of cofferdam. 
This paper presents a finite element study of the cofferdam of Zhuanghai artificial island. The purpose of the study is to evaluate the stability of the soil-structure system in terms of the consolidation process and the associated shear strength transformation. The critical situations of the cofferdam will be indicated.

\section{GEOTECHNICAL PARAMETERS OF SOILS}

The foundation at Zhuanghai artificial island is mainly composed of five soils, i.e. muck, mucky silty clay, silty clay, clay and fine sand. The muck has been excavated before construction. Nine soil layers, numbered as 1 9 from up down, are shown in Fig. (1) and Table 1. Standard penetration test, vane shear test and laboratory tests have been performed by Tianjin University to derive geotechnical parameters of foundation soils. The measured parameters are summarized in Table $\mathbf{1}$.

Since the clays are normal consolidated, so the lateral pressure coefficient $K$ is expressed as

$K=1-\sin \phi^{\prime}$

where $\phi^{\prime}$ is the effective internal friction angel of soil. The Poisson ratio $v$ can be written

$v=\frac{K}{1+K}$

and the Yang's Modulus $E$ is derived to be

$$
E=E_{s}\left(1-\frac{2 v^{2}}{1-v}\right)
$$

where $E_{s}$ is the oedometric modulus. The Yang's modulus and Poisson ratio of soil will later be used in finite element analysis are listed in Table 2.

Table 1. Property Parameters of Foundation Soils

\begin{tabular}{|c|c|c|c|c|c|c|}
\hline No. & Soil & $\begin{array}{c}\text { Depth } \\
(\mathbf{m})\end{array}$ & $\begin{array}{c}\text { Effective } \\
\text { Cohesion } \\
\text { (kPa) }\end{array}$ & $\begin{array}{c}\text { Effective } \\
\text { Internal } \\
\text { Friction } \\
\text { Angel } \\
\text { (deg.) }\end{array}$ & $\begin{array}{c}\text { Oedometric } \\
\text { Modulus } \\
\text { (MPa) }\end{array}$ & $\begin{array}{c}\text { Permeability } \\
\text { Coefficient } \\
(\mathbf{m} / \mathbf{s})\end{array}$ \\
\hline \hline 1 & Muck & $0.0 \sim 1.8$ & 7.1 & 2.3 & 1.9 & $5.0 \times 10^{-9}$ \\
\hline 2 & $\begin{array}{c}\text { Mucky } \\
\text { silty clay }\end{array}$ & $1.8 \sim 5.8$ & 9.6 & 3.3 & 3.2 & $1.0 \times 10^{-8}$ \\
\hline 3 & Silty clay & $5.8 \sim 10.6$ & 13.1 & 6.2 & 3.7 & $5.0 \times 10^{-8}$ \\
\hline 4 & $\begin{array}{c}\text { Mucky } \\
\text { silty clay }\end{array}$ & $10.6 \sim 11.2$ & 3 & 24.6 & 9.3 & $2.0 \times 10^{-9}$ \\
\hline 5 & Clay & $11.2 \sim 13.3$ & 14.2 & 10.3 & 2.6 & $5.0 \times 10^{-10}$ \\
\hline 6 & Silty clay & $13.3 \sim 19.0$ & 17.4 & 10.95 & 5.7 & $5.0 \times 10^{-9}$ \\
\hline 7 & Clay & $19.0 \sim 20.9$ & 21.8 & 13.8 & 9.6 & $3.0 \times 10^{-10}$ \\
\hline 8 & Fine sand & $20.9 \sim 28.7$ & 6.7 & 30.65 & 18.6 & $2.0 \times 10^{-6}$ \\
\hline 9 & Silty clay & $28.7 \sim 34.4$ & 17.6 & 15.95 & 6.3 & $5.0 \times 10^{-9}$ \\
\hline
\end{tabular}

The extended Drucker-Prager model implemented in the software ABAQUS (Version 6.7) [10] is used to describe the deformation of foundation soils. Associated flow rule is adopted, so the dilation angle is assumed to be identical to the friction angel. The suggested value of flow stress ratio is 0.8 , to ensure that the yield locus on the $\pi$-plate is close to the Mohr-Coulomb yield criterion.
Table 2. Yang's Modulus and Poisson Ratio of Foundation Soils

\begin{tabular}{|c|c|c|}
\hline No. & $\begin{array}{c}\text { Yang's Modulus } \\
\text { (MPa) }\end{array}$ & Poisson Ratio \\
\hline \hline 1 & 0.11 & 0.490 \\
\hline 2 & 0.27 & 0.485 \\
\hline 3 & 0.58 & 0.471 \\
\hline 4 & 5.3 & 0.369 \\
\hline 5 & 0.67 & 0.451 \\
\hline 6 & 1.55 & 0.448 \\
\hline 7 & 3.28 & 0.432 \\
\hline 8 & 12.60 & 0.329 \\
\hline 9 & 2.44 & 0.420 \\
\hline
\end{tabular}

\section{FINITE ELEMENT MODEL}

Due to the great length of the cofferdam, cofferdam-soil system can be assumed to be a plane strain problem. Fig. (2) shows the finite element mesh used in numerical analysis. Eight-node biquadratic elements are used in order to decrease the distortion of drainage rate near fabricated drain elements.

Hansbo [11] present a simple solution of vertical drains with regard to well resistance and smear effect. Hird et al. [12] performed an equivalent plain-strain analysis considering a unit cell of the vertical drain. Indraratna and Redana [13] developed the plane strain model to quantify the smear effect.

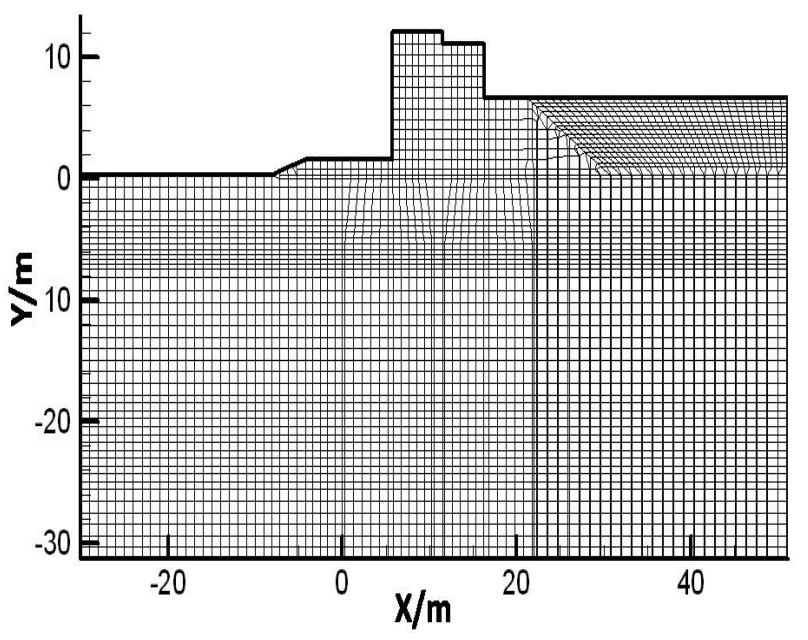

Fig. (2). Finite element mesh of cofferdam.

The vertical drain system is converted into equivalent plane strain by adjusting the spacing of the drain wall or the permeability of soil or both. Only the permeability of soil is adjusted in this study, using following formula [13]:

$$
\frac{k_{h p}}{k_{h}}=\frac{2}{3\left[\ln \left(\frac{R}{r_{s}}\right)+\left(\frac{k_{n}}{k_{s}}\right) \ln \left(\frac{r_{s}}{r_{w}}\right)-\frac{3}{4}\right]}
$$


where $k_{h p}$ and $k_{h}$ is the adjusted and unadjusted horizontal permeability coefficient of soil respectively, $R$ is the half of the space between vertical drains, $r_{s}$ is the radius of the smear area, $r_{w}$ is the equivalent radius of the vertical drains, $k_{s}$ is the permeability coefficient of the smear area.

Assuming that the radius of the smear area is $0.12 \mathrm{~m}$ and the horizontal permeability coefficient is $1 / 4$ of the undisturbed soil. Comprehensively considering the drains and the smear area, the horizontal and vertical permeability coefficients may be calculated by

$k_{h}=b_{s}+b_{w} / \frac{b_{s}}{k_{s}}+\frac{b_{w}}{k_{w}}$

and

$k_{v}=\frac{k_{s} b_{s}+k_{w} b_{w}}{b_{s}+b_{w}} \approx \frac{k_{w} b_{w}}{b_{s}+b_{w}}$

where $b_{w}$ and $b_{s}$ is the width of the drain wall and smear area respectively, $k_{w}$ is the permeation coefficient of the fabricated drains, and $k_{v}$ is the vertical permeability coefficient of the element of vertical drains. In this study, the width of elements of vertical drains is set to be $100 \mathrm{~mm}$. The permeability coefficient is adjusted once more. The water flux in vertical drains is assumed to be invariant. The adjusted permeability coefficients of the element of soil and vertical drain are listed in Table $\mathbf{3}$.

Table 3. Adjusted Permeability of Soil and Drain

\begin{tabular}{|c|c|c|c|}
\hline Depth (m) & $\begin{array}{c}\text { Horizontal } \\
\text { Permeability } \\
\text { Coefficient of } \\
\text { soils (m/s) }\end{array}$ & $\begin{array}{c}\text { Horizontal } \\
\text { Permeability } \\
\text { Coefficient of } \\
\text { Drains }(\mathbf{m} / \mathbf{s})\end{array}$ & $\begin{array}{c}\text { Vertical Per- } \\
\text { meability Coef- } \\
\text { ficient of Drains } \\
(\mathbf{m} / \mathbf{s})\end{array}$ \\
\hline \hline $2.8 \sim 5.8$ & $1.93 \times 10^{-9}$ & $1.02 \times 10^{-9}$ & $1.09 \times 10^{-3}$ \\
\hline $5.8 \sim 10.6$ & $9.65 \times 10^{-9}$ & $5.10 \times 10^{-9}$ & $1.09 \times 10^{-3}$ \\
\hline $10.6 \sim 11.2$ & $3.86 \times 10^{-10}$ & $2.04 \times 10^{-10}$ & $1.09 \times 10^{-3}$ \\
\hline $11.2 \sim 13.3$ & $9.65 \times 10^{-11}$ & $5.10 \times 10^{-11}$ & $1.09 \times 10^{-3}$ \\
\hline $13.3 \sim 17.1$ & $9.65 \times 10^{-10}$ & $5.10 \times 10^{-10}$ & $1.09 \times 10^{-3}$ \\
\hline
\end{tabular}

\section{RESULTS OF ANALYSIS}

\section{Deformation of Soil-Structure System}

The deformation when the construction is just completed is evaluated in this section. The final deformation is also assessed when the foundation soil is assumed to be completely consolidated.

Fig. (3) shows horizontal and vertical displacement contours of the soil-structure system when the construction is just completed. As shown in Fig. (3), the maximum horizontal displacement and settlement of the cylindrical soil retaining wall is $0.15 \mathrm{~m}$ and $0.55 \mathrm{~m}$, respectively. The differential settlement of the retaining wall is about $0.25 \mathrm{~m}$. The maximum horizontal displacement of the foundation soil is 0.35 $\mathrm{m}$, occurring underneath the foreshore toe of the bucket, as shown in Fig. (3a). The rotation of the cofferdam is calcu- lated to be 1.3 degree. The movement of the soil indicates a lateral outward trend and a potential general shear failure mode through the foundation.

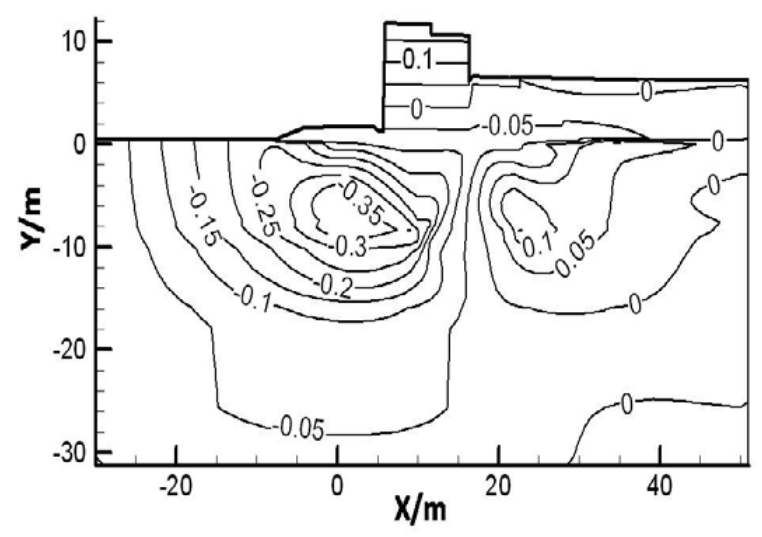

(a) Horizontal displacement (unit: m)

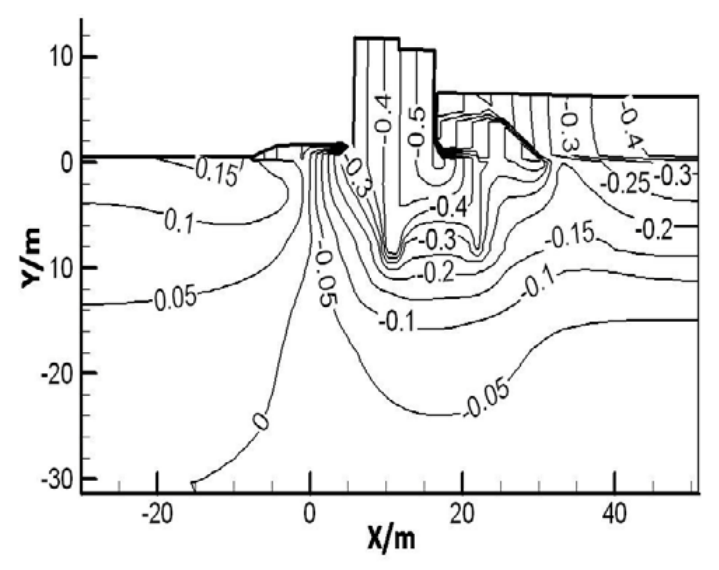

(b) Vertical displacement (unit: m)

Fig. (3). Displacements when construction is completed.

Secondary consolidation is not involved in this study, so the final displacement is mainly caused by the backfill soil behind the retaining wall. The displacement is calculated when the consolidation time is long enough after the construction. Fig. (4) illustrates the final displacements. Slight heave of the ground occurs at the toe of the foreshore side of the cofferdam.

As shown in Fig. (4), the maximum horizontal displacement and settlement of the cylindrical soil retaining wall is $0.15 \mathrm{~m}$ and $0.72 \mathrm{~m}$, respectively. The differential settlement of the retaining wall is about $0.20 \mathrm{~m}$. As the rotation of the retaining wall is only 1.0 degree, so the overturn stability of the retaining wall may not be very severe. However, the settlement, especially the differential settlement may be of concern.

By comparing the results in Figs. (3) and (4), it is indicated that the difference of the horizontal displacement of the retaining wall at the two concerned situations is very insig- 
nificant. However, the settlement of the retaining wall increases with time. The settlement of the retaining wall is $0.55 \mathrm{~m}$ when the construction is just completed, but it increases up to $0.72 \mathrm{~m}$ when the foundation is assumed to be fully consolidated.

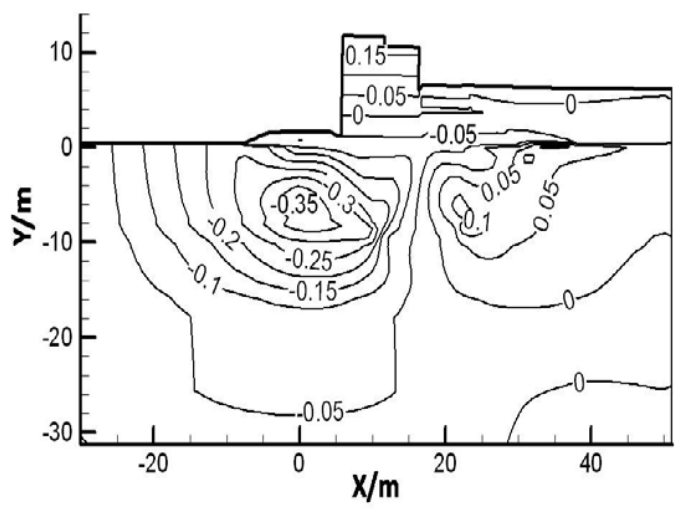

(a) Horizontal displacement (unit: m)

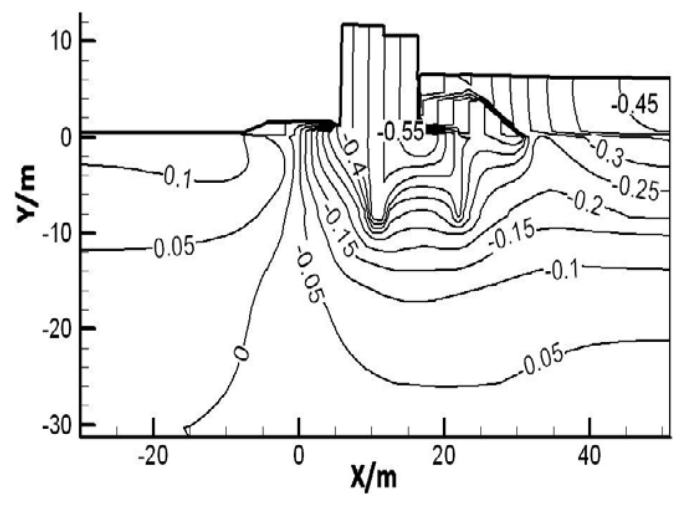

(b) Vertical displacement (unit: m)

Fig. (4). Final displacements.

Based on the analysis, it is found that most of the ground deformation occurs during the construction, which poses a threat to the stability of the structure. Deformation control is of importance and associated with the construction rate and procedures.

\section{Development of Excess Pore Pressures}

Excess pore pressure develops in the foundation soils during the progress of construction. Fig. (5) illustrates the excess pore pressure in foundation at three stages when the cylindrical retaining wall, the berm or backfill is completed.

Since the concrete cylinder and the steel bucket are impervious, so a permeability coefficient of $1 \times 10^{-13} \mathrm{~m} / \mathrm{s}$ is assumed for the bucket and cylinder. As a result, the excess pore pressure contours near the impervious materials appear singular and indicate no physical meanings.

Before the cylindrical wall is completed, the distribution of excess pore pressure is nearly symmetrical (Fig. 5a). With the progress of construction, the excess pore pressure at the onshore side of the cofferdam increase rapidly (Figs. 5b, 5c). The maximum excess pore pressure is $70 \mathrm{kPa}$ and takes

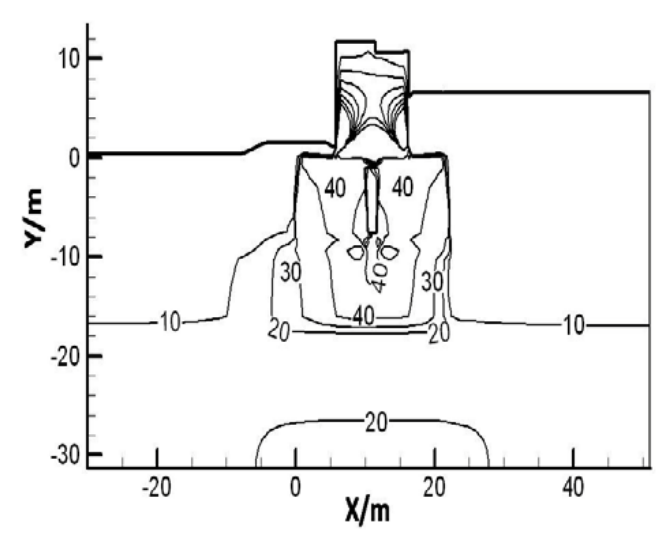

(a) The cylindrical wall is completed $(\mathrm{kPa})$

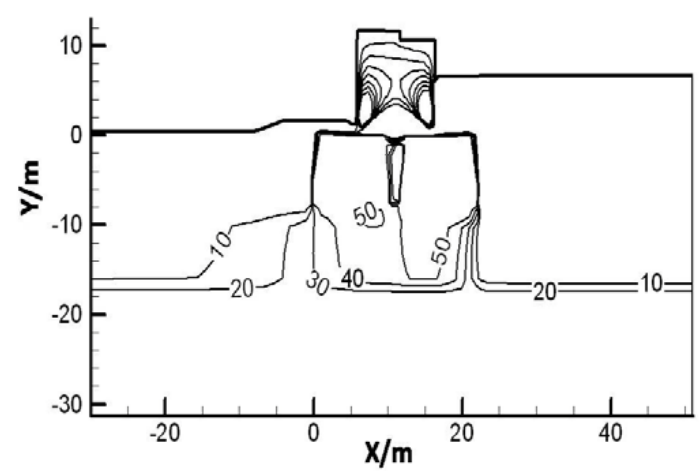

(b) The berm is completed $(\mathrm{kPa})$

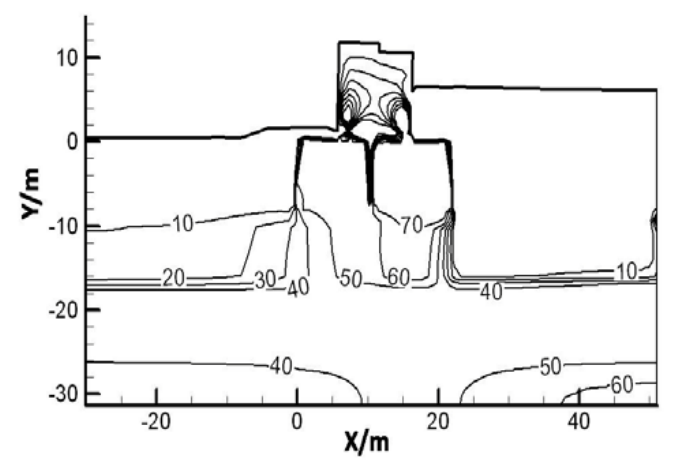

(c) The backfill is completed $(\mathrm{kPa})$

Fig. (5). Excess pore pressure during construction.

place underneath the bucket at the onshore side when the backfill is completed. Fortunately, the region of high excess pore pressure is quite restrained, it hence greatly reduce the risk of failure of the foundation.

A contrast model is performed to evaluate the effect of the vertical drains on development of excess pore pressure. The results are shown in Fig. (6). It is found that the excess pore pressure in the model with drains is evidently lower than that with no drains. In soil at a depth of $8 \sim 17.1 \mathrm{~m}$, the maximum pore pressure is less than $10 \mathrm{kPa}$ in the model with drains, but it is over $50 \mathrm{kPa}$ in the model with no drains. Beyond this region, high excess pore pressure exhibits in 


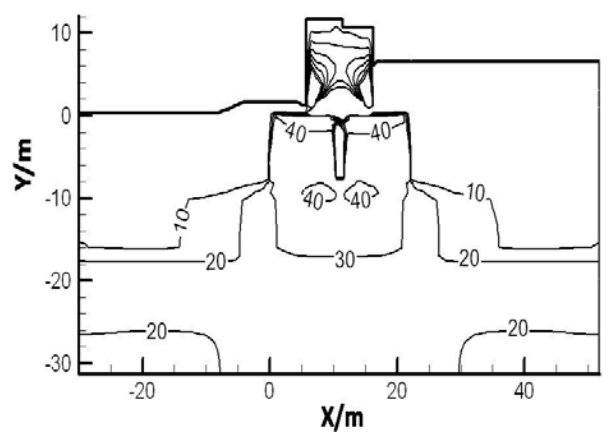

(a) The cylindrical wall is completed $(\mathrm{kPa})$

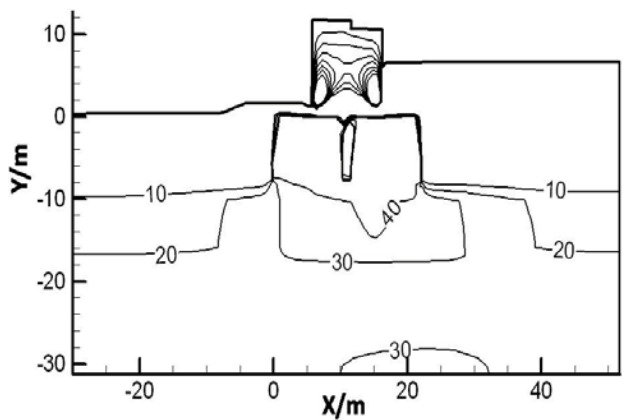

(b) The berm is completed $(\mathrm{kPa})$

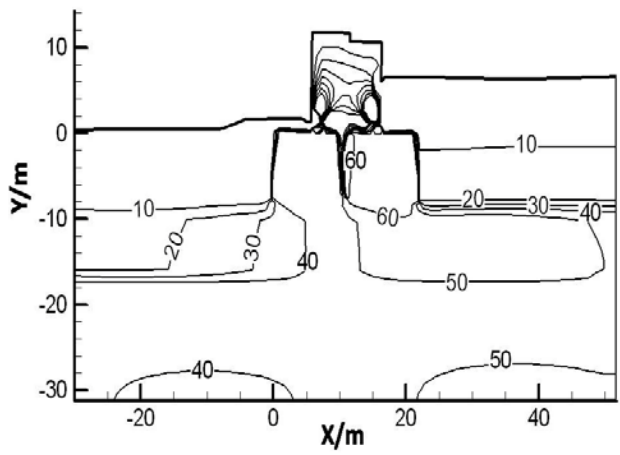

(c) The backfill is completed $(\mathrm{kPa})$

Fig. (6). Excess pore pressure in model with no drains.

both models. The vertical drains demonstrate effective in preventing high pore pressure.

The dissipation of the excess pore pressure is of particular significance regarding the long-term stability of the soilstructure system. Fig. (7) shows the dissipation process of excess pore pressure 3 - 24 months after construction, the effect of fabricated drains is also involved. As seen from Fig. (7), the excess pore pressure is quite low in the region incorporated with vertical drains, but remains almost unchanged with time beyond that region due to low permeability of the clays.

\section{CONCLUSIONS}

This paper presents a finite element simulation of a cofferdam incorporating bucket foundation in soft clays at Zhuanghai artificial island. Following conclusions can be drawn.

The maximum horizontal displacement and settlement of the reinforced concrete retaining wall is $0.15 \mathrm{~m}$ and $0.55 \mathrm{~m}$

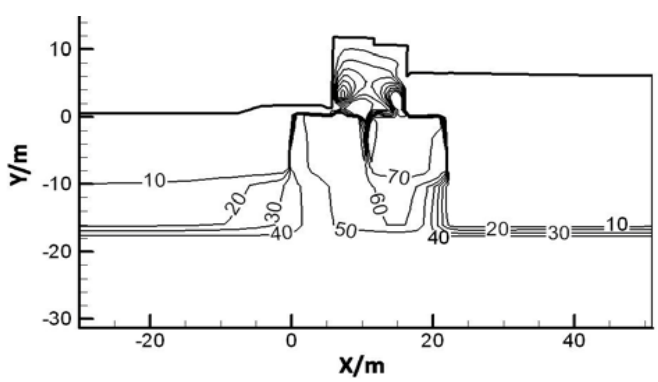

(a) 3-month after the construction completed

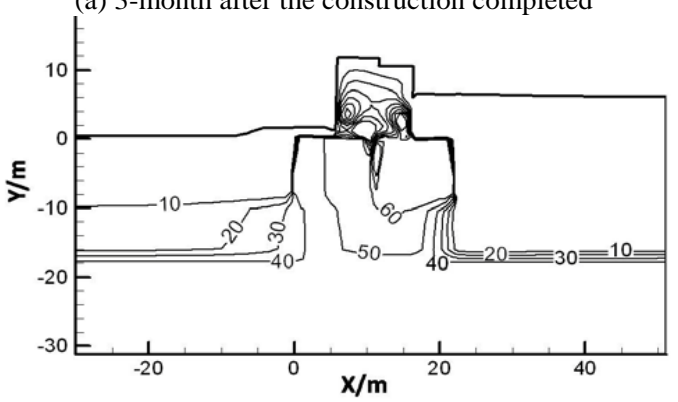

(b) 6-month after the construction completed

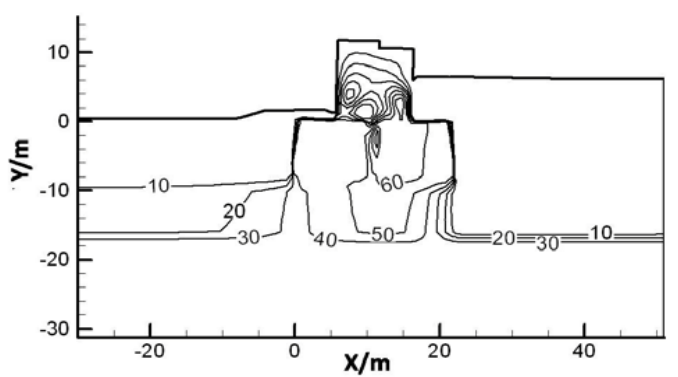

(c) 12-month after the construction completed

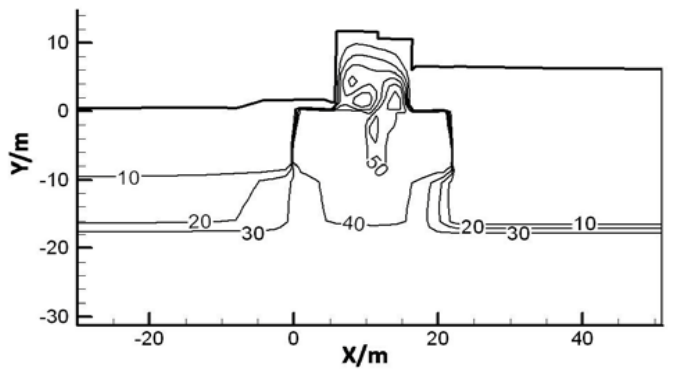

(d) 24-month after the construction completed

Fig. (7). Excess pore pressure after construction $(\mathrm{kPa})$.

when the construction is just completed. The maximum horizontal displacement of the foundation soil is $0.35 \mathrm{~m}$, occurring underneath the foreshore toe of the bucket. The movement of the soil indicates a lateral outward trend.

Most of the ground deformation occurs during the construction, especially the horizontal displacements of the retaining wall and foundation soils. However, the settlement of the retaining wall increases from $0.55 \mathrm{~m}$ at the completion of the construction up to $0.72 \mathrm{~m}$ when the foundation is fully consolidated.

The prefabricated drains demonstrate very effective in preventing high pore pressure and thus potential failure through the foundation soils. Beyond the region improved by vertical drains, high excess pore pressure exhibits even 2 years after the completion of the construction. 


\section{ACKNOWLEDGEMENT}

The research work was funded by the National Basic Research Program of China (2007CB714102) and National Natural Science Foundation of China (50679035).

\section{REFERENCES}

[1] X.B. Lu, S.Y. Wang, J.H. Zhang, G.L. Sun and Z.M. Shi, "Experimental study of pore pressure and deformation of suction bucket foundations under horizontal dynamic loading," China Ocean Engineering, vol. 19, pp. 671-680, 2005.

[2] R. Dyvik, K.H. Andersen, C. Madshus and T. Amundsen, "Model test of platforms, I description," Journal of Geotechnical Engineering ASCE, vol. 115, pp. 1532-1549, 1989.

[3] R. Dyvik, K.H. Andersen, C. Madshus and T. Amundsen, "Model test of platforms, II interpretation," Journal of Geotechnical Engineering ASCE, vol. 115, pp. 1550-1568, 1989.

[4] M.A. Allard, K.H. Andersen and J. Hermstad, "Centrifuge model tests of a gravity platform on very dense sand: I: testing technique and results," In: International Conference on the Behavior of Offshore Structures, Oxford, UK, 1995, pp. 231-254.

[5] S. El-Gharbawy and R. Solson, "The cyclic pullout capacity of suction caisson foundations," In: Proceeding 9th Offshore and Polar Engineering Conference, Brest, France, 1999, pp. 660-667.

[6] J.H. Zhang, L.M. Zhang and X.B. Lu, "Centrifuge modeling of suction bucket foundations for platforms under ice-sheet-induced cyclic lateral loadings," Ocean Engineering, vol. 34, pp. 10691079, 2007.

[7] K. Wu, M.T. Luan, Q.L. Fan and Z.Y. Wang, " Numerical analysis of bearing capacity of suction bucket foundation under combined loads", In: the Ninth International Conference on Engineering Structural Integrity Assessment, Beijing, China, 2007, pp. 594-596.

[8] J.M. Zhang, J.H. Zhang, G. Wang and Y. Chen, "Stability of jetties for channel protection in soft soils at huanghua port," Ocean Engineering, vol. 35, pp. 1716-1726, 2008.

[9] J.M. Zhang, J.H. Zhang, G. Wang and Y. Chen, "Safety evaluation of breakwaters based on physical and numerical modeling", Ocean Engineering, vol. 36, pp. 852-862, 2009.

[10] ABAQUS Inc., ABAQUS/Standard User's Manual, Version 6.7. 2007.

[11] S. Hansbo, "Consolidation of fine-grained soils by prefabricated drain," In: Proceedings of 10th International Conference of Soi Mechanics and Foundation Engineering, Stockholm, Sweden, 1981, pp. 677-682.

[12] C.C. Hird, I.C. Pyrah and D. Russell, "Finite element modeling of wick drains beneath the embankments on soft ground," Geotech nique, vol. 42, No. 3, pp. 499-511, 1992.

[13] B. Indraratna, and I.W. Redana, "Plane-strain modeling of smear effects associated with verti cal drains, "Journal of Geotechnical and Geoenvironmental Engineering, vol. 123, No. 5, pp. 474-478, 1997.

(c) Zhang and Zhang; Licensee Bentham Open.

This is an open access article licensed under the terms of the Creative Commons Attribution Non-Commercial License (http://creativecommons.org/licenses/by-nc/3.0/) which permits unrestricted, non-commercial use, distribution and reproduction in any medium, provided the work is properly cited. 